\title{
EXPLOSIVITY OF POWDERED PAINTS IN LACQUERING CABINS
}

\author{
Eva VELIČKOVÁ ${ }^{1}$, Michaela PERĎOCHOVÁ2 ${ }^{2}$, veronika FOLDYNOVÁ ${ }^{3}$
}

Review article

\begin{tabular}{|c|c|}
\hline Abstract: & $\begin{array}{l}\text { Danger of explosion exists in process of lacquering in which powdered paint is present. } \\
\text { This danger is especially probable when powdered paint occurs in roiling state in the } \\
\text { presence of an oxidant (mostly in the form of air). If there is sufficient energy source, } \\
\text { conditions for initiation are created. Safety must be ensured on the workplace with danger } \\
\text { of explosion. This safety must be in compliance with the requirements of the legislation } \\
\text { approved in the European Union and their implementation in the laws of Czech Republic. }\end{array}$ \\
\hline Keywords: & $\begin{array}{l}\text { Lacquering cabin, powdered paint, danger of explosion, fire technical characteristic, } \\
\text { safety data sheet. }\end{array}$ \\
\hline
\end{tabular}

\section{Introduction}

High probability of formation of explosion exists in lacquering cabins. It is caused by presence of excitable and explosive lacquering materials, voltage on the spray guns in connection with excitable material, formation of explosive atmosphere thanks to accumulation of applied material, bad ground of lacquered products and settling applied material in cabin, filters or cyclones.

Fires occur in lacquering cabins every year in the Czech Republic and in the world. The most famous recent fire is fire of powdered paint in the company Ronal in Stare Civice on 18. 12. 2009. This accident occurred on the lacquering device in which powdered paint catched fire. Next fire became in lacquering cabin in Loucky on 2. 12. 2005. Fire struck technology of exhaustion of cabin and damaged ventilation technique, filters and junk rings. The fire was caused by technical fault on the fan of exhaust equipment device.

The cloud of particles, which forms at spraying powdered materials, can be electrically charged and therefore it can cause charging of spray device, sprayed object or any other object (including people), which are located in the spraying area. If cloud of particles is flammable, there is danger of initiation of explosion. The greatest danger is at electrostatic application of powders and flakes.

\section{Materials and methods}

According to regulation of the Government No. 176/2008 Coll., about technical requirements for machinery, machinery must be proposed and constructed so that it performs its function and can be operated, adjusted and maintained without exhibition of people to risk, when these operations are carried out under the assumed conditions with regard to any reasonable predictable incorrect use. Every risk must be excluded during assumed lifetime of machinery, including transport, installation, demounting, decommissioning and crushing. If machinery meets the relevant provision of the harmonized European standard in which link is published in Official gazette of European Union or harmonized Czech technical standard or international technical standard in member state of the European Union, and these the relevant provision of the harmonized European standard relates to the relevant basic requirement, it is considered that this basic requirement is satisfied (Government Regulation, 2008).

According to regulation of the Government No. 406/2004 Coll., about the detailed requirements for ensuring safety and health protection at work in potentially explosive atmosphere, manner of organization of work and working and technological processes must be determined for safety operation and using device on workplaces in potentially explosive atmosphere. Employer must accept these precautions for guarantee of explosion protection:

VŠB - Technical University of Ostrava, Faculty of Safety Engineering, Ostrava, Czech Republic, eva.velickova@vsb.cz VŠB - Technical University of Ostrava, Faculty of Safety Engineering, Ostrava, Czech Republic, michaela.perdochova@vsb.cz VŠB - Technical University of Ostrava, Faculty of Safety Engineering, Ostrava, Czech Republic, veronika.foldynova@vsb.cz 
- to prevent the formation of an explosive atmosphere,

- to prevent the initiation of an explosive atmosphere,

- to reduce the harmful effects of an explosion to ensure health and safety of employees (Government Regulation, 2004).

According to Act No. 133/1985 Coll., about Fire Protection, legal and self - employed natural persons operating activities with increased and high fire danger have obligation to have at disposal fire technical and explosion characteristics of produced, used, processed or stored substances and materials needed for assessment of preventive precaution for protection of life, health of persons and property. Activities with increased fire danger are activities at which combustible dust or vapors of flammable liquids occurs in production or handling in air or in a facility to such an extent that formation of explosive concentration cannot be excluded or flammable dust settles in continuous layer at least $1 \mathrm{~mm}$ (Act, 1985).

According to notice No. 246/2001 Coll., about assessment of conditions of fire safety and performance of state fire supervision (ordinance about fire protection), fire danger is defined as probability of formation of fire or explosion followed by fire. Fire technical characteristic means the property of substance expressed in measurable value or determined on the basis measurable values of more partial properties or phenomenon that articulates behavior of substance in the process of burning or related to it. Technical safety parameter is fire technical characteristic that expresses qualitative or quantitative properties of the flammable substance. Activity is considered as safe in terms of danger of formation of fire or explosion followed by fire when technical safety parameter is followed under predictable conditions (Notice, 2001).

If situation, when danger of explosion threatens, can occur at operation of device, it is necessary, according to Regulation of Government No. 23/2003 Coll. of 9 December 2002 laying down technical requirements for devices and protective systems intended for use in potentially explosive atmosphere, to equip operated devices with suitable protective systems or control and regulatory devices that prevent explosion or to minimize its consequences.

\section{Description of own process of lacquering}

Fluidized powdered paints are transported to the spray guns. Fluidization is carried out in powdered centres, where the suction system (2) is immersed in a container with the addition of fluidizing air into the powdered paint. The fluidized powder is fed into the suction system (2) from the container to the injectors and finally to the spray guns by means of fluidizing air. The amount of powder that flows into the spray gun can be increased by addition of dosing air. Flow of powder is accelerated by addition of auxiliary air. Depending on the application, there are used for powdered lacquering powdered guns Tribo or Corona. Powdered particles are charged and applied to the lacquered object. Considerable amount of powder do not snap at application on lacquered object. This overspray is evacuated and led through the suction pipe (4) into a cyclone (5).

By means of high rotation, air is separated from powder in cyclone. Dust particles get on the walls of the cyclone by centrifugal powers of rotation. Powder slides down wall of cyclone to the sorting device - the screen where gross impurities are catched. By means of peristaltic conveyor, recycled powder is transported back to the container in the powdered centre of the powder. At the end of the process output air is polished from residues of powder, which was evacuated in slight quantity to the end of the filter (Fig. 1).

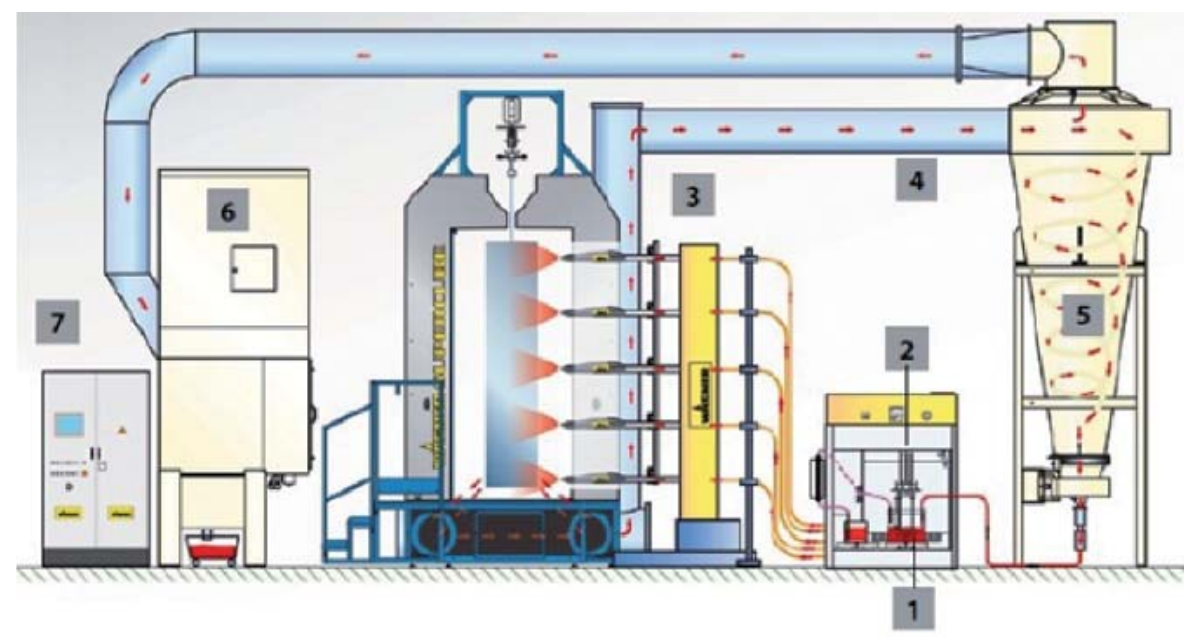

Fig. 1 Circulation of powdered paint at the application (Available at: http://www.wagner.cz) 


\section{Powdered paint}

Powdered paint is finely dispersed particles of resins, polymers, pigments, fillers and additives, which remain during storage under appropriate conditions finely dispersed and these particles create continuous coating after melting and appropriate curing at temperature $180-200{ }^{\circ} \mathrm{C}$.

Powdered paint, on basis of its physical chemical properties, belongs to colloidal and dispersion systems for which linear dimension of particles is one of the defining characteristics. Small linear size leads to significant increase of surface of area at given weight of system. Total area of dust depends on size its particles.

The burning rate of combustible dust closes on speed of combustion of gases and combustion process runs perfectly. The dispersion of dust is not permanent in machineries, devices and facilities and is affect by moisture of raw material and air and velocity of movement of the air in the room, etc.

Heterogeneous mixtures of dust and air begin to burn because they are initiated by some source of ignition. Ignition and propagation of flame occur in whole heterogeneous system when combustible substance and air are in certain relative ratios. Minimum concentration $\left[\mathrm{g} \cdot \mathrm{m}^{-3}\right]$, at which dust has ability to ignite, is called lower explosive limit.

The process of combustion of dust in such a concentration is characterized by low temperature and pressure and low speed of expansion of the flame (Orlíková et al.1991).

Ignition and explosion of dust is possible only when these conditions at disposal in given place and in same time:

- exothermic oxidisable substance - combustible dust,

- sufficient amount of oxygen,

- effective source of ignition.

For formation of explosion of combustible dust it is necessary to fulfill following conditions:

- sufficient fineness of combustible dust,

- concentration of the mixture located inside explosive file (between upper and lower explosive limit).

By constant $K_{s t}$, dusts are classified according to the standards C CSN ISO6184-1 or VDI3673 into classes of explosion St 1 to St 3, when class of explosion St 3 is the most dangerous. (See Tab. 1)
Tab. 1 Classes of explosion of industrial dusts (Orlíková et al., 1999)

\begin{tabular}{|c|c|}
\hline Class & $\mathbf{K}_{\text {st }}\left[\mathbf{M P a} \cdot \mathbf{m}^{\mathbf{s}^{-1}}{ }^{\mathbf{}}\right]$ \\
\hline St 1 & $0-20$ \\
\hline St 2 & $20-30$ \\
\hline St 3 & $>30$ \\
\hline
\end{tabular}

Dusts of different materials vary their behaviour during heating. Dusts in the form of aerogel are evaluated according to different values of self-ignition temperature. For aerosols, explosive limits are characterized. Aerosols, that have a low value of lower explosive limit, are more dangerous because these concentrations may be generated during industrial production (Orlíková, 1976).

Combustible dust creates an explosive atmosphere only at concentrations within explosive limits. Although cloud with very high concentration has not to be explosive, it can get into explosive limits by decrease of concentration below upper explosive limit.

A cloud of dust from any source of leakage, including layer or pile, can generate explosive atmosphere of dust. Layers of dust, that do not generate roiling dust, can be ignited by self-ignition or exposure to hot surfaces or flow of heat and cause danger of fire or overheating of device. On fire layer can function as ignition source for explosive atmosphere.

Ignition sources should be excluded in places where explosive clouds of dust can generate. Subsequently, after the completion of area classification, assessment of hazard can be done for decision whether consequences of ignition of explosive atmosphere require the use of device with higher protection level (EPL) or justification of the use of device with lower protection level (EPL) than would be normally required (ČSN EN ISO 8130-14, 2005, ISO 8130-14, 2004).

The following items are evaluated at classification of areas with explosive atmosphere with dust:

- whether dust is combustible or not,

- properties of materials for given process,

- nature of escape from some part of technology,

- operating regimes and regimes of maintenance of technology, including cleaning,

- additional information regarding devices and safety.

Although only danger of roiling dust is taken into account in definition of hazardous zones, layers of dust must be taken into account also that can generate cloud of dust by swirling. The procedure for determination of hazardous zones is following: 
- to determine whether material is flammable and suitable for purpose of evaluating of sources of ignition; to determine properties of materials particle size, moisture content, minimum ignition temperature of dust in a layer of roiling dust, electrical resistivity and corresponding group of dust:

- group IIIA for flammable airborne particles,

- group IIIB for non - conductive dusts,

- group IIIC for conductive dusts,

- to identify places where devices contain dust or sources of leak of dust,

- to determine probability that dust will escape from these sources and probability of formation of explosive mixture of dust with air in different parts of operation (IEC60079-10-22010, IEC 60079-10-2, 2009).

After performance these steps, zones and their extent can be determined (see Tab. 2).

Tab. 2 Classification into zones depending on time of presence of flammable dust (ČSN EN60079-10-2, 2010, IEC 60079-10-2, 2009)

\begin{tabular}{|c|c|}
\hline $\begin{array}{c}\text { Presence of flammable } \\
\text { dust }\end{array}$ & $\begin{array}{c}\text { Consequent device of } \\
\text { area with clouds of dust }\end{array}$ \\
\hline Permanent degree of leak & 20 \\
\hline Primary degree of leak & 21 \\
\hline Secondary degree of leak & 22 \\
\hline
\end{tabular}

Zone 20 is an area in which an explosive atmosphere is created by cloud of roiling flammable dust in air and this atmosphere is present permanent or for long time period or often.

Zone 21 is an area in which an explosive atmosphere can be created by cloud of roiling flammable dust in air and this atmosphere can generate occasionally in normal operation.

Zone 22 is an area in which formation of explosive atmosphere, consisting of a cloud of roiling flammable dust in air, is not probable during normal operation and if it occurs, it is present only for short time period.

The range of zones for explosive atmosphere with dust is defined as distance from the edge of the source of leak in any direction to a place that is not already considered as dangerous in connection with this zone.

Explosions can be caused by:

- processed materials in used devices, protective systems and their components,
- released materials from devices, protective systems and their components,

- materials in vicinity of devices, protective systems and their components,

- materials from which devices, protective systems and their components are made.

Safety depends not only on devices, protective systems and components, but also depends on the processed material and way of its use. Producer has to think how and for what purposes, devices, protective systems and components will be used and this fact takes into account in design and construction. Only by such way, risks associated with devices, protective systems and components can be reduced (ČSN EN $1127-1$ ed. 2, 2012, EN 1127-1, 2011).

The probability of emergence of dangerous explosive atmosphere depends on:

- presence of flammable substances,

- degree of dispersion of flammable substances (e.g. gases, vapors, mists and dusts),

- concentration of flammable substances in air in explosive range,

- quantity of explosive atmosphere sufficient for causing of injury or damage in case of fire.

At assessment of probable presence of dangerous explosive atmosphere, possible formation of explosive atmosphere must be taken into account. This formation of explosive atmosphere is caused by chemical reactions, pyrolysis and biological processes of present materials. If it is not possible to estimate probability of formation of dangerous explosive atmosphere, it must be assumed that such atmosphere is always present (ČSN EN 60079-1022010, IEC 60079-10-2, 2009).

Flammable substances must be considered as materials that can create explosive atmosphere, as long as investigation of their properties does not prove that these substances are not able to spontaneous propagation of explosion in mixture with air. At assessment of probable presence of dangerous explosive atmosphere, possibility of formation of explosive atmosphere must be taken into account that is caused by chemical reactions, pyrolysis and biological processes of present materials (ČSN EN 1127-1ed. 2, 2012, EN 1127-1, 2011).

\section{Risk of explosion of combustible dust during application of powdered paints}

At coating of powdered paints in manual or automatic spray cabin, dangerous of explosion is formed by overspray of powdered paint. Explosive 
atmosphere of dust and air occurs also in the cyclone separators and the filters of systems of recuperation of powdered paint.

During operation, swirling of separated dust occurs in cyclone separators. For these devices, permanent occurrence of explosive atmosphere of mixture of dust with air is assumed during operation. Separation of the finest fraction of dust proceeds in the filters. If filter is equipped with system of automatic cleaning of the filter medium by compressed air, strong swirling of dust and formation of dangerous explosive atmosphere occur during cleaning in interior of the filter. The initiation may be caused by static electricity and in the case of suction of hot particles from the technology connected to system of exhaust of dust. By systems of pneumatic transport of powdered materials, formation of explosive atmosphere can be expected in transportation pipelines and in storage tanks in the phase of their filling and emptying.

In case that speed of the transported powdered material is not too enough, formation of dust deposits occurs inside of the transportation pipeline. Initiation of explosive atmosphere can be cause by penetration of metal body into system of pneumatic transport which can cause sparks and discharge of static electricity generated relative contacts of particles of transported material and by friction between transported material and surface of piping of pneumatic transport.

Hazard of explosion, which threatens in various technologies with occurrence flammable dust, brings increased requirements for guarantee of safety. The Labour code is very general in this area. It is stated that employer is obliged to look for risks, evaluate them and take action to remove them, respectively to minimize them. Other related legislation does not indicate exact procedure and rules for guarantee safety. It is inter alia thereby that every operation is different and depends on analysis and evaluation of risks.

At evaluation of risks of explosion according to ČSN EN $1127-1$ ed. 2, it is recommended to proceed systematically for every device and possible operational situation. These recommends are in agreement with the principles of good practice for implementing directive 1999/92/EC and can be summarized into the following sequence steps and together with them corresponding flowchart, together with conditions and principles of its use:

- identification of dangerous substances in technological process and assessment of probability of formation of dangerous explosive atmosphere on basis of operating conditions,
- determination of hazard of ignition and assessment of probability of formation of potential ignition sources,

- evaluation of potential effects of explosion in case of ignition,

- application of technical and organizational measures for restriction harmful effects of explosion,

- evaluation of achievement of prescribed level of protection.

\section{Results}

According to ČSN EN 1127-1 ed. 2, it is necessary to identify dangerous substances in technological process and to determine probability of formation of dangerous explosive atmosphere. According to Act No. 133/1985 Coll., legal and self - employed natural persons operating activities with increased and high fire danger have obligation to have at disposal fire technical and explosion characteristics of substances occurring in technological process.

As already it was mentioned, ignition and explosion are inter alia possible at sufficient fineness of dust. In following Fig. 2, 3 and 4, results of sieve analysis of three samples of powdered paints are showed.

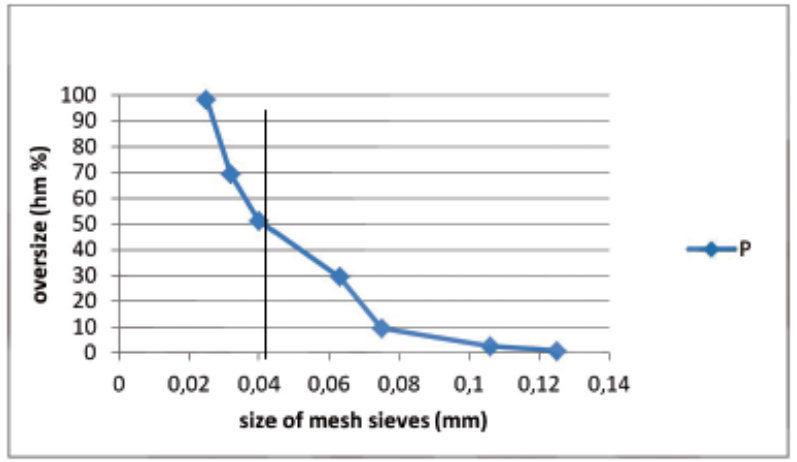

The mean grain size: $0,041 \mathrm{~mm}$

Fig. 2 Sieve analysis of black paint MN007D, Š. NH29368ZB

Fire technical and explosion characteristics of powdered paints are not at disposal on many workplaces. Suppliers often give at disposal safety data sheets for powdered paints, but values of fire technical characteristics are not entirely accurate or these values are showed in relatively wide range. 


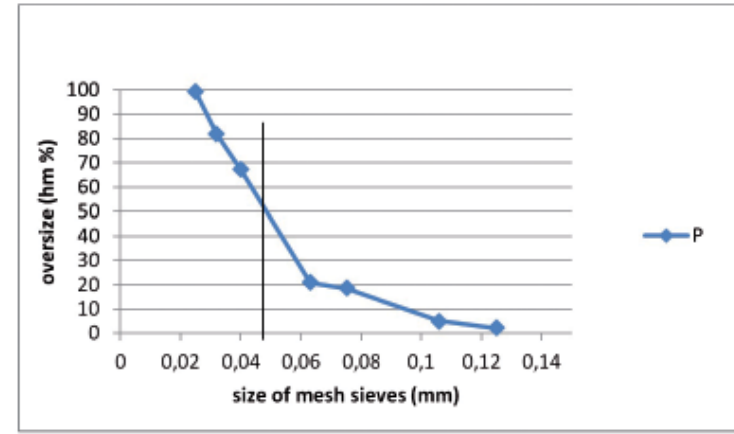

The mean grain size: $0,049 \mathrm{~mm}$

Fig. 3 Sieve analysis of red paint SG 804F, Š NM94808ZB

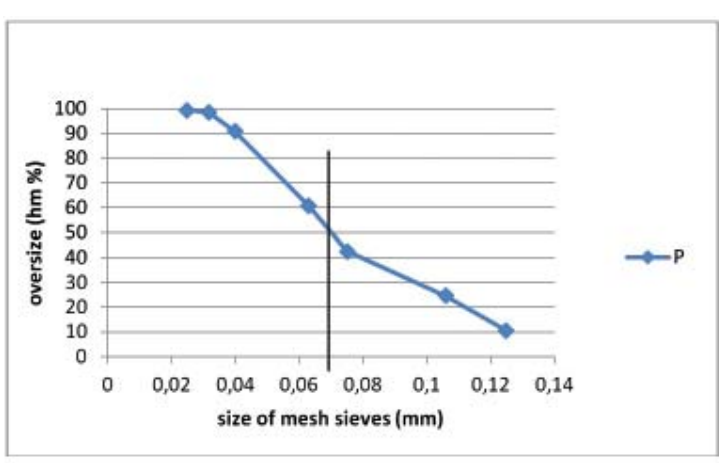

The mean grain size: $0,07 \mathrm{~mm}$

Fig. 4 Sieve analysis of white paint ML432E, Š NM9397

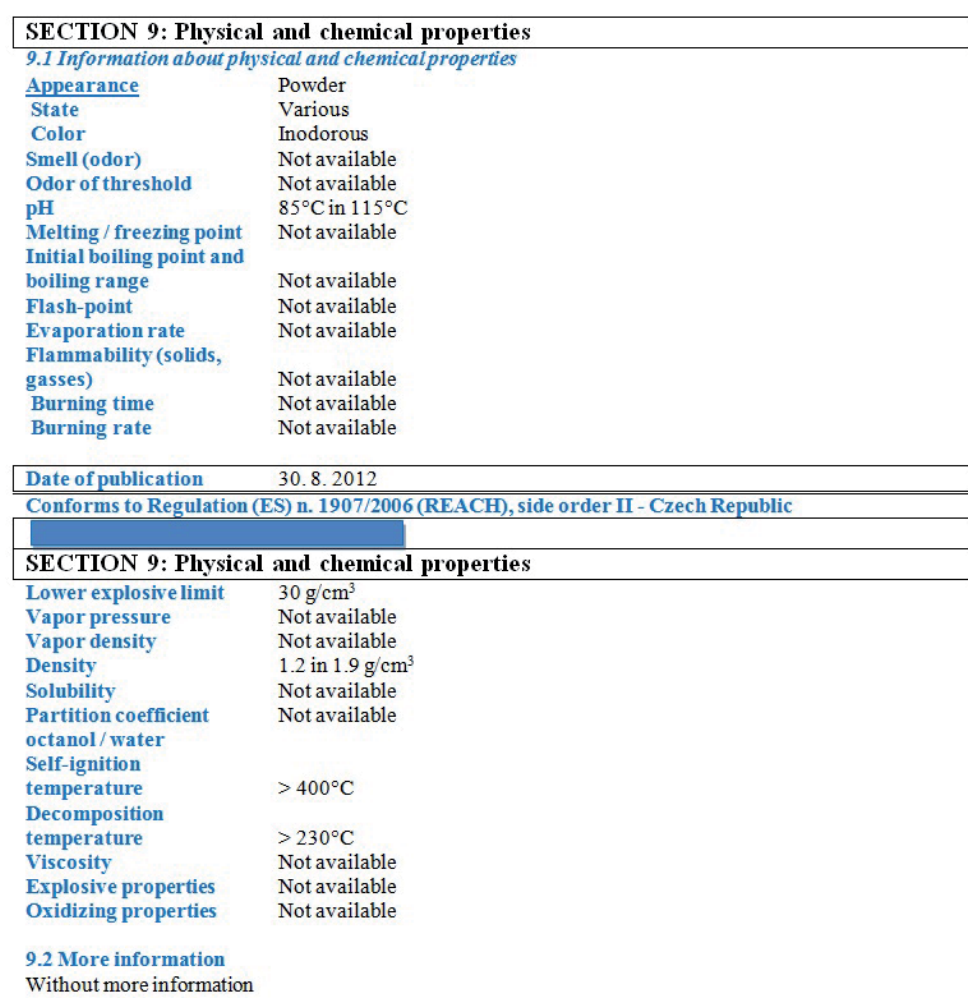

Fig. 5 Example of the part of safety data sheet
On these examples of the safety data sheets (see Fig. 5 and Fig. 6), it is pointed to reality that although safety data sheets are available on workplace, values of fire technical characteristics are not mentioned or they are not accurate. Additionally these values of fire technical characteristics are same in safety data sheets for all types of paints of one producer.

\begin{tabular}{|c|c|c|}
\hline \multicolumn{3}{|c|}{$\begin{array}{l}\text { 9 PHYSICAL AND CHEMICAL PROPERTIES } \\
\text { 9.1 Information about the properties of mixtures }\end{array}$} \\
\hline & \multirow{2}{*}{$\underline{\text { Test method }}$} \\
\hline Physical state & fine powder & \\
\hline Odor & not pleasant & - \\
\hline True density (at $23^{\circ} \mathrm{C}$ ) & $1,2-1,9 \mathrm{~g} / \mathrm{cm}^{3}$ & ISO $8130-2 /-3$ \\
\hline Bulk density (at $23^{\circ} \mathrm{C}$ ) & $400-1000 \mathrm{~kg} / \mathrm{cm}^{3}$ & \\
\hline Lower explosive limit dust / air mixture & $20-70 \mathrm{~g} / \mathrm{cm}^{3}$ & ISO $8130-4$ \\
\hline $\begin{array}{l}\text { Recommended value of dust concentration in } \\
\text { the plant }\end{array}$ & $<10 \mathrm{~g} / \mathrm{cm}^{3}$ & \\
\hline Solubility in water & insoluble & \\
\hline Softening point & $>50^{\circ} \mathrm{C}$ & method "hot plate" \\
\hline Flash point of the mixture vapor/ air & $450-600^{\circ} \mathrm{C}$ & EN 50281-2-1 \\
\hline Minimum ignition energy & $5-20 \mathrm{~mJ}$ & - \\
\hline \multicolumn{3}{|c|}{ Powder coating can be predisposed to explosion as fine organic material according to group of explosivity Stl } \\
\hline Vapor pressure & not available & - \\
\hline $\mathrm{pH}$ of water & $\mathrm{pH}$ of water is unchanged & - \\
\hline Ignition temperature & not available & - \\
\hline \multicolumn{3}{|c|}{$\begin{array}{l}\text { Designed lower explosive limits (LEL) are among these values - according to specific physical and chemical } \\
\text { properties (in the case of conventional powdered paints) }\end{array}$} \\
\hline \multicolumn{3}{|c|}{$\begin{array}{l}\text { 9.2 Other properties } \\
\text { The decomposition of product by heat; hazardous products of decomposition; dangerous reactions; inability of } \\
\text { application during normal use. In case of doubt, please contact your supplier of paints. }\end{array}$} \\
\hline
\end{tabular}

Fig. 6 Example of the part of safety data sheet

In Tab. 3, the comparison of measured values of fire technical characteristics with values reported in Safety Data Sheets is performed.

According to ČSN EN 3821, minimum ignition energy (MIE) of explosive mixture of dust and air is minimum electrical energy, accumulated on capacitor, which is sufficient at discharge to cause ignition of the most easily ignitable mixture of given dust under specified test conditions.

Above given table (see Tab. 4) shows that some values MIE, measured on provided samples, are not in the extent given in safety data sheets.

\section{Conclusion}

At comparison of safety data sheets of individual produces, it was found that safety data are same for different paints at individual producers. Some data, given in safety data sheets, are different than real data and some data are not given. Some lacquering cabins had not at disposal safety data sheets at all. Thereby more attention should be devoted to content of safety data sheet. Already according to Act No. 133/1985 Coll., it is necessary to have at disposal fire technical and explosive characteristics of used substances on workplace with increased and high fire danger. 
Tab. 3 Comparison of measured values of fire technical characteristics with values reported in Safety Data Sheets

\begin{tabular}{|l|c|c|}
\hline & $\begin{array}{c}\text { Data in Safety } \\
\text { Data Sheets }\end{array}$ & $\begin{array}{c}\text { Measured } \\
\text { values }\end{array}$ \\
\hline $\begin{array}{l}\text { Lower explosive } \\
\text { limit }\end{array}$ & $20-70 \mathrm{~g} / \mathrm{cm}^{3}$ & $20 \mathrm{~g} / \mathrm{m}^{3}$ \\
\hline $\begin{array}{l}\text { Flashpoint dust/air } \\
\text { mixture }\end{array}$ & $450-600^{\circ} \mathrm{C}$ & $400^{\circ} \mathrm{C}$ \\
\hline $\begin{array}{l}\text { The maximum } \\
\text { explosion pressure }\end{array}$ & $6,9 \mathrm{bar}$ \\
\hline $\begin{array}{l}\text { The maximum rate } \\
\text { of rise in pressure }\end{array}$ & & $562 \mathrm{bar} / \mathrm{s}$ \\
\hline Constant $\mathrm{K}_{\mathrm{St}}$ & $181 \mathrm{~m} \cdot \mathrm{bar} / \mathrm{s}$ & $153 \mathrm{~m} . \mathrm{bar} / \mathrm{s}$ \\
\hline Class of explosion & $\mathrm{St} 1$ & $\mathrm{St} 1$ \\
\hline
\end{tabular}

Tab. 4 Comparison of measured values MIE of three samples with values reported in the Safety Data Sheets

\begin{tabular}{|l|c|c|}
\hline & $\begin{array}{c}\text { Measured value MIE } \\
\text { [mJ] }\end{array}$ & $\begin{array}{c}\text { Value of MIE } \\
\text { in the safety } \\
\text { data sheet [mJ] }\end{array}$ \\
\hline White color & 26 & \multirow{2}{|c|}{$5-20$} \\
\hline Black color & $\begin{array}{c}\text { sample is almost } \\
\text { insensitive to initiation } \\
\text { by electrostatic spark }\end{array}$ & \\
\hline Red color & 8 & \\
\hline
\end{tabular}

\section{Acknowledgments}

The paper was processed thanks to support provided by the project SP2013/28, Explosivity of Powdered Paints in Lacquering Cabins.“

\section{References}

Act (1985). Zákon č. 133/1985 Sb. České národní rady ze dne 17. prosince 1985 o požární ochraně, v platném znění (in Czech)

ČSN EN ISO 8130-14 (67 3151) (2005) Práškové nátěrové hmoty - Část 14: Terminologie, Český normalizační institut, Praha, 2005. 12 s. (in Czech)

ČSN EN 1127-1 ed. 2 (38 9622) (2012)Výbušná prostředí - Prevence a ochrana proti výbuchu - Č́st 1: Základní koncepce a metodika, Úřad pro technickou normalizaci, metrologii a státní zkušebnictví, Praha, 2012. 40 s. (in Czech)

ČSN EN 13821(38 9602) (2005) Prostředí s nebezpečím výbuchu - Prevence a ochrana proti výbuchu - Stanovení minimální zápalné energie směsi prachu se vzduchem, Praha, 2005. 20 s. (in Czech)

ČSN EN 60079-10-2 (33 2320) (2010) Výbušné atmosféry - Část 10-2: Určování nebezpečných prostorů Výbušné atmosféry s hořlavým prachem, Úřad pro technickou normalizaci, metrologii a státní zkušebnictví, Praha, 2010. 28 s. (in Czech)

EN 1127-1 (2011) Explosive atmospheres - Explosion prevention and protection - Part 1: Basic concepts and methodology, 2011

EN 13821 (2002) Potentially explosive atmospheres - Explosion prevention and protection - Determination of minimum ignitron energy of dust/air mixture, 2002

Government Regulation (2001). Vyhláška Ministerstva vnitra č. 246/2001 Sb., ze dne 29. června 2001 o stanovení podmínek požární bezpečnosti a výkonu státního požárního dozoru (vyhláška o požární prevenci) (in Czech)

Government Regulation (2004). Nařízení vlády č. 406/2004 Sb. ze dne 2. června 2004 o bližších požadavcích na zajištění bezpečnosti a ochrany zdraví při práci v prostředí s nebezpečím výbuchu (in Czech)

Government Regulation (2008). Nařízení vlády 176/2008 Sb. ze dne 21. dubna 2008 o technických požadavcích na strojní zařízení (in Czech)

IEC 60079-10-2(2009) Explosive atmospheres - Part 10-2: Classification of areas - Combustible dust atmospheres, 2009

ISO 8130-14 (2004) Powder coatings - Part 14: Terminology, 2004

ORLÍKOVÁ, Kateřina (1976). Chemie hořlavin. 1. vydání. Ostrava: BSP Edičního střediska VŠB Ostrava, 1976. 72 s. (in Czech)

ORLÍKOVÁ, Kateřina, DANIHELKA, Pavel, KOZUBEK, Ervín (1991). Chemie hořlavin a produktů hoření. 1. vydání. Ostrava: Ediční středisko VŠB Ostrava, 1991. 102 s. ISBN 80-7078-036-3. (in Czech)

ORLÍKOVÁ, Kateřina, ŠTROCH, Petr (1999). Chemie procesů hoření. 1. vydání. Ostrava: Sdružení požárního a bezpečnostního inženýrství, 1999. 87 s. ISBN 80-86111-39-3.(in Czech) 